\title{
Guest Editorial of ICEEE-2020 EEST special issue
}

\author{
Eyup Dogan ${ }^{1,2} \cdot$ Ilhan Ozturk ${ }^{3}$ Lin Sea Lau ${ }^{4}$
}

Accepted: 25 October 2021 / Published online: 15 November 2021

(c) The Author(s), under exclusive licence to Springer Science+Business Media, LLC, part of Springer Nature 2021

The life of human beings is closely tied to energy. To meet energy demand, fossil fuels are excessively consumed by societies, resulting in the increase of carbon emissions, which in turn cause climate change (Pizarro-Irizar et al. 2020). Thus, the decarbonization of the energy system is necessary to hedge global warming. In this direction, it is vital to explore and promote sustainable energy to decrease the damaging impacts on the environment. Renewable energy sources are a major contributor to this solution and bear great potential to lead the energy transition thanks to advances in technologies that are low-cost now. In particular, solar and wind energy can play a significant role in the shift from conventional to non-conventional energy production and consumption, while they can affect several macroeconomic indicators (Nikas et al. 2020).

The ICEEE'2020 conference (ICEEE: International Conference on Economics, Energy and Environment) took place in Cappadocia, Turkey on June 23-25, 2020. Six presentations with a statistical taste were selected for the preparation of six manuscripts, which after due review provided six articles for this special issue published in Environmental and Ecological Statistics (EEST) on the theme of "Economics of Energy and Environment". These six articles can be described as follows.

Yilmaz et al. (2021) determine the design criteria of habitable spaces with microclimate data for ecological urbanization. Their statistical results indicate a difference in the relationship between the thermal comfort and air pollution of the residential textures and the sky view factor (SVF) value of the study area according to seasons.

Handling Editor: Pierre R. L. Dutilleul.

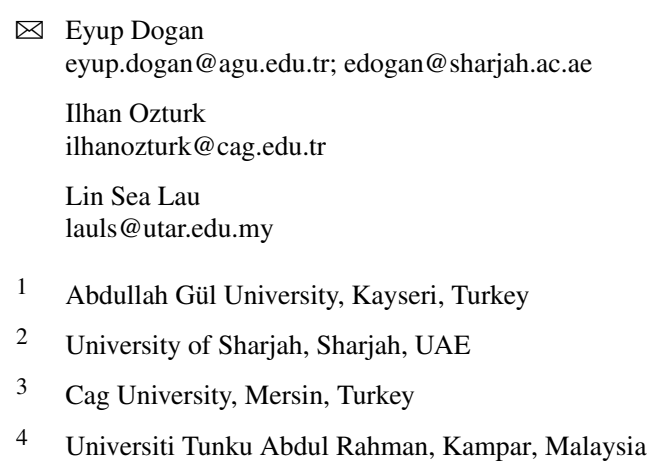


A strong relationship is found between pollutants and SVF, while it is weaker for green areas. Air pollution was observed to have the lowest density in the areas where detached house types are located among different residential textures.

Ching et al. (2021) investigate the effect of environmental degradation on food production based on the Cobb-Douglas production function. They also test the role of research and development (R\&D), capital and labor on food production. The three estimators provide consistent results for a panel of 53 countries over the period 1996-2017. First, emissions of carbon dioxide $\left(\mathrm{CO}_{2}\right)$ are harmful to food production. Second, both capital and R\&D are found to have a positive relationship with food production, while an increase in labor tends to reduce food production. Furthermore, the Dumitres$\mathrm{cu}-\mathrm{Hurlin}$ test reveals a bidirectional causality (i) between food production and $\mathrm{CO}_{2}$ emissions and (ii) between R\&D and food production.

İçöz et al. (2021) developed an alternative particulate matter measurement system that is portable, inexpensive, and integrated with cloud computing. The system allows real-time distant monitoring of PM particles with high spatial resolution in the meter range. The developed sensor system is able to provide air quality data in correlation with the existing stations $\left(R^{2}=0.87\right)$. The statistical comparison between the developed system and the reference methods revealed that the two systems produced statistically equivalent results in detecting the variations of the particulate matter.

Ozturk et al. (2021) examine the decoupling of $\mathrm{CO}_{2}$ emissions from the economic growth through the employment of the Tapio decoupling index and the decomposition of $\mathrm{CO}_{2}$ emissions into its pre-determined factors through the Log Mean Divisia Index (LMDI) technique for Pakistan, India, and China (PIC) over 1990-2014. The results of the Tapio elasticity analysis show that in a few years, the environmental impact has been decoupled from the economic growth in the PIC countries. However, Pakistan experienced relatively more negative decoupling; India mostly experienced weak decoupling and expensive coupling, while China exhibited weak decoupling in several years.

Bibi et al. (2021) uncover the causality between biomass energy consumption (BEC) and $\mathrm{CO}_{2}$ emission in the United States, using the method of bootstrap Granger estimates for the period 1981-2019. A one-way relationship was found, from biomass energy consumption to $\mathrm{CO}_{2}$ emissions, using the Granger causality test. The durability of the estimated vector autoregressive (VAR) model has been calculated by considering the structural changes. Results show that BEC has both positive and negative effects on $\mathrm{CO}_{2}$ emissions in sub-samples, and $\mathrm{CO}_{2}$ emissions also have a causative relationship with biomass energy consumption.

Çitak et al. (2021) explore the link between energy consumption and $\mathrm{CO}_{2}$ emission, and attempt to extend present knowledge by identifying sector-specific impacts of electricity consumption on $\mathrm{CO}_{2}$ emission. Findings suggest that the nexus between electricity consumption and $\mathrm{CO}_{2}$ emission is sector-specific, as well as distributionspecific in Turkey. In particular, a positive but weak impact of industrial electricity consumption on $\mathrm{CO}_{2}$ emission is found. Yet, the effects become stronger for the lowest and highest quantiles of $\mathrm{CO}_{2}$ emissions due to industrial electricity consumption, suggesting an alert for a shift in the current energy policies of the country.

The Guest Editors would like to express their sincere thanks and gratitude to the Authors who provided very interesting and complementary contributions and to the 
Reviewers who provided expert and detailed feedback. Without their help, it would have been impossible to prepare this EEST special issue so diligently and efficiently.

\section{References}

Bibi A, Zhang X, Umar M (2021) The imperativeness of biomass energy consumption to the environmental sustainability of the United States revisited. Environ Ecol Stat. https://doi.org/10.1007/s10651-02100500-9

Ching S-L, Yii K-J, Ng C-F, Choong C-K, Lau L-S (2021) Is food production vulnerable to environmental degradation? A global analysis. Environ Ecol Stat. https://doi.org/10.1007/s10651-021-00493-5

Çıtak F, Şişman MY, Bağcı B (2021) Nexus between disaggregated electricity consumption and $\mathrm{CO}_{2}$ emissions in Turkey: new evidence from quantile-on-quantile approach. Environ Ecol Stat. https://doi. org/10.1007/s10651-021-00504-5

İçöz E, Malik FM, İçöz K (2021) High spatial resolution IoT based air PM measurement system. Environ Ecol Stat. https://doi.org/10.1007/s10651-021-00494-4

Nikas A et al (2020) Sustainable and socially just transition to a post-lignite era in Greece: a multi-level perspective. Energy Sources Part B: Econom Plan Policy 15(10-12):513-544. https://doi.org/10.1080/ 15567249.2020.1769773

Ozturk I, Majeed MT, Khan S (2021) Decoupling and decomposition analysis of environmental impact from economic growth: a comparative analysis of Pakistan, India, and China. Environ Ecol Stat. https:// doi.org/10.1007/s10651-021-00495-3

Pizarro-Irizar C et al (2020) Assessing stakeholder preferences on low-carbon energy transitions. Energy Sources Part B: Econom Plan Policy 15(10-12):455-491. https://doi.org/10.1080/15567249.2020. 1812767

Yilmaz S, Sezen I, Sari EN (2021) The relationships between ecological urbanization, green areas, and air pollution in Erzurum/Turkey. Environ Ecol Stat. https://doi.org/10.1007/s10651-021-00484-6

Eyup Dogan is currently working as an Associate Professor of Economics in the Department of Finance and Economics at University of Sharjah, UAE. In addition, he is Editor for Environmental Science and Pollution Research. He received his Ph.D. in Economics from Clemson University, USA, in 2014. His fields of interest are energy economics and environmental economics in which the relationship among macro-variables of the economy, energy consumption and environmental indicators are investigated. He has published around 40 articles at high-ranked international journals and attended a number of international conferences.

Ilhan Ozturk is Professor of Economics at Cag University, Mersin, Turkey, where he is also the Director of the Higher Vocational School. His research interests include energy economics and international economics. He has published more than 155 papers in international journals such as Energy Economics, Energy Policy, Applied Energy, Renewable and Sustainable Energy Reviews, Ecological Indicators, Energy and etc. and participated in many international conferences. He has been invited as a Keynote Speaker in several international conferences. He is the editor of IJEEP and IJEFI and he has been member of editorial board in many international journals.

Lin Sea Lau is a lecturer at the Faculty of Business \& Finance (Department of Economics), University Tunku Abdul Rahman (UTAR), Malaysia. She received her Master degree in Management from the University of Southern Queensland, Australia and her Bachelor degree in Economics from Universiti Utara Malaysia. Currently, she is pursuing her PhD with University Tunku Abdul Rahman. 